\title{
Systemic effects of unspecific inflammatory reaction at traumatic brain injury
}

\author{
Sergey V. Ziablitsev, Svetlana V. Pishchulina, Svetlana V. Kolesnikova, Ruslan N. Boris \\ Ukrainian Science-Practical Centre of Endocrine Surgery, Transplantation of Endocrine Organs and \\ Tissues Ministry of Healthcare of Ukraine, Kyiv, Ukraine; e-mail: zsv1965@gmail.com
}

\begin{abstract}
To determine the role of systemic effects of inflammation at traumatic brain disease caused by severe traumatic brain injury. The study is performed on 65 white outbred male rats. TBI is applied with one blow on animal's cranial vaults with blow energy of $0.52 \mathrm{~J}$. The rate of mortality within the first 5 days after the injury is $87 \%$. Experimental animals have got severe closed TBI. Blood contents of circulating immune complexes, C-reactive protein, ceruloplasmin, proinflammatory - interleukins $(I L-1 \beta, I L-6, I L-8$ and tumor necrosis factor $\alpha-T N F-\alpha$ ) are investigated. The circulating immune complexes levels are increased 3.1 times in 24 hours and 4.4 times on the 5th days of trauma reflecting the progressive accumulation of metabolites and toxins in brain tissue and in the blood of injured animals. Blood levels of C-reactive protein are markedly increased in all periods of observation exceeding the control levels 3.5 times in 3 hours and 21.3 times after 5th day of trauma. Thus the study results suggest that the acute phase of systemic inflammation sets at the end of the 1st day after the trauma and it progresses in the course of traumatic brain disease. Blood contents of IL-1 $\beta$ increases continuously: 4.7 times in 3 hours; 7.6 times in 24 hours; and 17.4 times on the 5 th day after trauma. The other interleukins levels are also increased but to a lesser extent. The coherence of changes in levels of circulating immune complexes, acute-phase proteins and interleukins indicates a pathogenic pattern of the acute period of traumatic disease at traumatic brain injury: spreading of damage processes with the involvement of body organs and tissues and the establishment of a systemic inflammatory reaction stage from the second day of posttraumatic period.

Key words: traumatic brain injury; acute phase proteins; proinflammatory interleukins.
\end{abstract}

\section{INTRODUCTION}

In recent years systemic signs of the organism's involvement in the inflammatory reaction are in increasing interest. The systemic inflammatory reaction is involved in pathogenesis of extreme and terminal conditions [1-3]. It is known that systemic effects of inflammation are mediated by different mediators including cytokines, prostaglandins, kinins, and hormones, of which proinflammatory interleukins are the most important [4-6].

Along with fever, intoxication, leukocytosis and an increased erythrocyte sedimentation rate the systemic effects of inflammation include an increase in acute phase proteins (positive acute phase reactants), of which C-reactive protein (CRP) and ceruloplasmin (CP) are most researched $[3,7,8]$. Unspecific signs of the inflammatory reaction include increased blood levels of proinflammatory cytokines as well as a presence of circulating immune complexes (CIC) which consist of endogenous antigens formed from tissue necrosis, complement and precipitating antibody $\operatorname{IgM}_{1} \mathrm{IgG}_{1}, \mathrm{IgG}_{2}$ and $\mathrm{IgG}_{3}$.

It can be assumed that traumatic brain injury (TBI) which is due to severe traumatic disease causes systemic inflammatory reaction that in turn results in multiple organ dysfunction syndrome.

\section{METHODS}

The study was performed on 65 white male rats weighing $200 \pm 10 \mathrm{~g}$. TBI was applied with one blow on the cranial vault by means of free-falling plummet [9]. The blow energy was $0.52 \mathrm{~J}$;

(C) Sergey V. Ziablitsev, Svetlana V. Pishchulina, Svetlana V. Kolesnikova, Ruslan N. Boris 
and the mortality within the first 5 days after the injury was $87 \%$. Animal experiment was carried out according to European Convention for the Protection of Vertebrate Animals used for Experimental and Other Scientific Purposes (Strasbourg, 1986). The subsequent brain autopsy revealed the presence of subperiosteal, subdural, epidural and skull base hematomas, as well as foci of crushed brain tissue and dedrit in the blow zone and swelling of the pituitary gland. The received date suggested that experimental animals have got severe closed TBI with skin hematomas, fractures of the cranial vault without displacement, crushing of the parietal and temporal lobes cortex, a damage of the brain in the form of diffuse petechial hemorrhages and "cladding" hematoma (in the blow zone) the frontal and temporal lobes bases (in the anti-blow zone). The control group included 15 sham-operated animals. Blood contents of CIC, CRP, CP, proinflammatory interleukins: interleukin $1 \beta$ (IL-1 $\beta$ ), 6 (IL-6), 8 (IL-8) and tumor necrosis factor $\alpha$ (TNF- $\alpha)$ were investigated in 3, 24, 48, 72 hours and in the 5th day after trauma. The CIC and CP contents were measured photometrically using a spectrophotometer SPECORD-200 (Germany). The CRP blood levels were measured by means of ELISA kit from DRG International, Inc. (United States). The interleukins blood levels were measured using the reagents "ProCon" (Russia) with the result registration on the reader PR2100 ("Sanofi Diagnostic Pasteur", France). The study results were processed using the method of multiple comparisons in the program of the statistical analysis MedCalc v.15.11.0 (MedCalc Software bvba, 1993-2015).

\section{RESULTS AND DISCUSSION}

The results of investigation of the CIC and acute-phase proteins (CRP and the CP) in the blood of animals with TBI are presented in Table 1. It shows an increase in the CIC levels 1.4 times after 3 hours after trauma. More significant increase of the $\mathrm{CIC}$ is revealed in the course of TBI: 3.1 times in 24 hours and 4.4 times in the 5 th days $(\mathrm{P}<0.05$ in both cases $)$.

It is known that severe TBI causes brain tissue crushing and the blood brain barrier impairment. As a result neuronal antigens enter the bloodstream and bind antibodies activating the complement system and producing the CIC [1]. Thus an increase in the CIC can be conceded as unfavorable pathogenic factor that reflects accumulation of metabolites and toxins in brain tissue and in the blood of injured animals. The immune complexes are deposited in vessel walls causing generalized inflammation in the microcirculation vessels $[6,8]$. On the other hand a marked increase in the CIC within the early period of traumatic disease can be regarded as a protective reaction designed to binding an excess of neuronal antigens. However further increase in the CIC must be interpreted as a damage reaction leading to a generalization of the inflammatory reaction.

Blood CRP content is markedly increased in all periods of observation. It scientifically

Table1. Blood contents of the circulating immune complexes (CIC) and acute-phase proteins (CRP and CP) in the course of traumatic brain injury; $M \pm \mathbf{m}$

\begin{tabular}{|l|c|c|c|c|c|c|}
\hline \multirow{2}{*}{ Index } & \multirow{2}{*}{ Control } & \multicolumn{5}{|c|}{ Time after trauma } \\
\cline { 3 - 7 } & & 3 hours & 24 hours & 48 hours & 72 hours & 5 days \\
\hline $\mathrm{CIC}, \mathrm{units}$ of OD & $40.6 \pm 5.12$ & $55.4 \pm 5.57$ & $124.2 \pm 10.3 *$ & $167.3 \pm 17.8 *$ & $170.4 \pm 16.7 *$ & $175.9 \pm 18.4^{*}$ \\
$\mathrm{CRP}, \mathrm{mg} / \mathrm{L}$ & $1.52 \pm 0.09$ & $5.32 \pm 0.48 *$ & $16.03 \pm 2.08^{*}$ & $17.55 \pm 2.46^{*}$ & $28.59 \pm 2.37 *$ & $32.46 \pm 2.52 *$ \\
$\mathrm{CP}, \mathrm{mmol} / \mathrm{L}$ & $2.34 \pm 0.26$ & $5.47 \pm 0.46^{*}$ & $7.85 \pm 0.67 *$ & $3.57 \pm 0.36$ & $1.42 \pm 0.11$ & $0.47 \pm 0.03 *$ \\
\hline
\end{tabular}

$\mathrm{P}<0.05$ compared with the average values of the control group 
increases (3.5 times) in 3 hours after trauma. In 24 hours after trauma the CRP content increases 3 times comparing to those of the 3-hours level and this exceeds its control levels 10.5 times. The CRP content continuously increases thus exceeding its control levels 18.8 times in 72 hours and 21.3 times in the 5 th day.

CRP is a major component of the acute phase of inflammation. It is actively involved in the formation of protein-ligand complexes, which are then removed by the system of mononuclear macrophages [1]. Furthermore, CRP inhibits and neutralizes toxic protease molecules. In this regard, CRP is considered the most sensitive and specific clinical and laboratory markers of acute inflammation [5].

In our opinion, such a pronounced increase in the content of CRP, as well as an increase in the content of CIC suggests that the acute phase of inflammation sets by the end of the 1st day after the trauma. Hence, the early stage of TBI can be referred to as the inflammatory stage. Further increase in CRP indicates the progression of the inflammatory response and its generalization.

In recent years $\mathrm{CP}$ is viewed as one of the acute phase proteins [7]. Blood CP levels changes ambiguously within the course of traumatic disease. They increase in 3 and 24 hours after trauma exceeding their control levels 2.3 and 3.3 times correspondently $(\mathrm{P}<0.05$ in both cases). However further the blood CP levels decrease in 72 hours and in the 5th day after trauma to $61 \%$ and $20 \%$ of their control levels correspondently $(\mathrm{P}<0.05$ in both cases $)$.

The increase in the blood CP content at the first days after injury is associated with the stimulating effect of inflammatory mediators on its hepatic synthesis during the acute phase of inflammatory response. The subsequent decline in the blood $\mathrm{CP}$ content is likely due to the exhaustion of serum antioxidant enzymes to which $\mathrm{CP}$ belongs because of its ability to bind oxygen free radicals and to inactivate them [7]. Second day after trauma is characterized by the development of systemic effects of inflammation thus it can be considered a turning point in the course of post-traumatic period.

On the first day after trauma inflammation can be activated by proinflammatory interleukins [4], of which IL- $1 \beta$ is known as a major mediator of inflammation. It is released by macrophages, B-lymphocytes and fibroblasts. In the brain IL$1 \beta$ is formed, as well as other proinflammatory interleukins, by glial cells in the affected and in the perifocal areas $[3,6]$. TNF- $\alpha$ is another inflammatory mediator producing by activated monocytes and macrophages in the site of injury. It is responsible for synthesis of the key nuclear transcription factor NF-kB, which switches the spectrum of the synthesized proteins to inflammatory factors - cytokines and adhesion molecules $[4,10]$. IL- 6 is a interleukin of "secondary cascade" because its synthesis is activated by TNF- $\alpha$ and IL- $1 \beta$ [5]. IL-6 stimulates B-cells for the production of antibodies. IL-6 is also responsible for the induction of acute phase inflammatory response via its stimulation of the liver to produce acutephase proteins. IL- 8 is released by activated macrophages, endothelial and epithelial cells. It is a chemotaxis factor for neutrophils, Tlymphocytes, macrophages, lymphocytes and eosinophils, thereby contributing to secondary alteration, development edema, and spreading of the damage zone [5].

The results of blood interleukins contents in the in the course of traumatic brain injury are shown in the table 2 .

In our study, blood content of IL- $1 \beta$ increases continuously: 4.7 times in 3 hours; 7.6 times in 24 hours; and 17.4 times in the 5 th day after trauma. The content of TNF- $\alpha$ increases 1.8 times in 3 hours; 2.2 times in 24 hours; and 2.9 times in the 5 th day after trauma $(\mathrm{P}<0.05$ in all cases $)$. There is a maximal increase in the content of both IL- $1 \beta$ and TNF- $\alpha$ on the 5 th day after trauma. IL-1 $\beta$ increases more 
Table 2. Blood interleukins contents in the course of traumatic brain injury, $M \pm \mathbf{m}$

\begin{tabular}{|c|c|c|c|c|c|c|}
\hline \multirow{2}{*}{ Index } & \multirow{2}{*}{ Control } & \multicolumn{5}{|c|}{ Time after trauma } \\
\cline { 3 - 7 } & & 3 hours & 24 hours & 48 hours & 72 hours & 5 days \\
\hline IL-1 $\beta . \mathrm{pkg} / \mathrm{ml}$ & $3.28 \pm 0.25$ & $15.42 \pm 1.48^{*}$ & $24.83 \pm 2.37^{*}$ & $49.75 \pm 5.33^{*}$ & $55.43 \pm 6.37^{*}$ & $57.22 \pm 5.61^{*}$ \\
$\mathrm{TNF}-\alpha . \mathrm{pkg} / \mathrm{ml}$ & $29.52 \pm 3.32$ & $52.06 \pm 4.29^{*}$ & $66.28 \pm 7.49^{*}$ & $76.58 \pm 8.7 *$ & $81.09 \pm 7.53^{*}$ & $86.27 \pm 8.29^{*}$ \\
$\mathrm{IL}-6 . \mathrm{pkg} / \mathrm{ml}$ & $4.28 \pm 0.44$ & $10.27 \pm 1.55^{*}$ & $15.86 \pm 1.63^{*}$ & $27.39 \pm 3.60^{*}$ & $30.28 \pm 3.09^{*}$ & $33.92 \pm 3.59^{*}$ \\
$\mathrm{IL}-8 . \mathrm{pkg} / \mathrm{ml}$ & $11.23 \pm 1.28$ & $15.39 \pm 2.48$ & $36.94 \pm 3.57^{*}$ & $45.84 \pm 3.28^{*}$ & $42.38 \pm 4.58^{*}$ & $47.38 \pm 5.60^{*}$ \\
\hline
\end{tabular}

$\mathrm{P}<0.05$ compared with the average values of the control group

than TNF- $\alpha$ indicating its greater involvement in the inflammatory process at traumatic disease. The content of IL- 6 exceeds its control levels 2.4 times in 3 hours; 3.7 times in 24 hours and 7.9 times in the 5 th day after trauma.

The content of IL-8, exceeds its control levels 1.4 times in 3 hours after trauma but it is not statistically significant $(\mathrm{P}>0.05)$. Significant increase in IL-8 content occurs only after 24 hours - by 3.3 times; and in the 5 th day it exceeds the control 4.2 times.

Assessment of the interleukins blood content dynamics one can note the succession of cytokines cascade (Fig. 1).

The highest increase in the blood IL$1 \beta$ levels reflects its role in pathogenesis of inflammation at traumatic disease: IL- $1 \beta$ can be regarded as major reactant of the immune system. Changes in the blood contents of IL-6 и TNF- $\alpha$ are similar to those of IL- $1 \beta$ but their increase is less significant. In our opinion this reflects sequential activation primary and secondary mediators of inflammation at traumatic brain in TBI. Marked increase in secondary mediators in the blood in 48 hours after trauma indicates likely the formation of a new stage of the pathogenesis of inflammatory reaction. Generalization of inflammation is suggested by "cytokine storm" which is revealed in our study. Coherence of changes in the levels of interleukins, the CIC and the acute-phase proteins shows significant

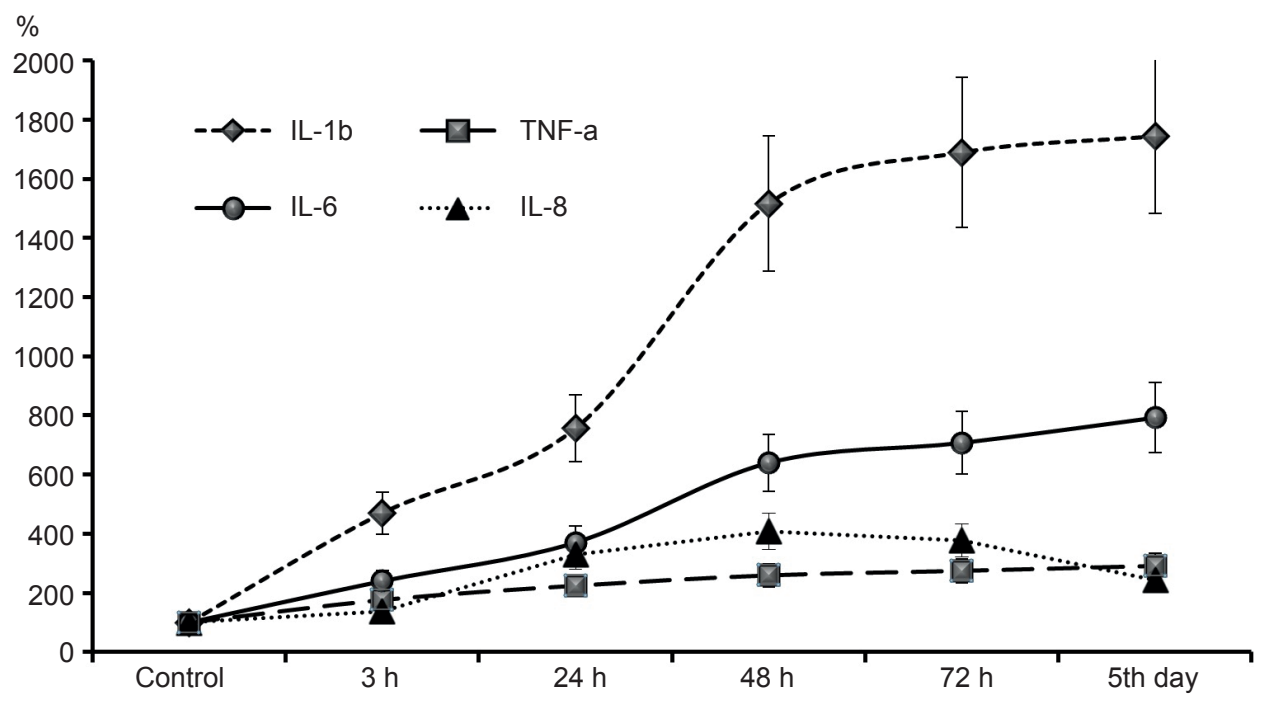

Fig. 1. Contents of proinflammatory interleukins in the course of posttraumatic period (all indexes are expressed in $\%$ of the control group levels, which are $100 \%$ ) 
feature of the pathogenesis of this period of traumatic disease - the generalization of the inflammatory response involving the organs and tissues.

\section{CONCLUSION}

Thus, the study of the blood levels of CIC, CRP, $\mathrm{CP}$ and proinflammatory interleukins in the course of severe TBI reveals a common pattern in the reaction of pro-inflammatory cascade markers with a maximum gain on the second day of post-traumatic period, reflecting the initial activation of the inflammatory response with further it generalization.

The initial moderate increase in the blood levels of interleukins can be regarded as the response of the immune system to damage which contributes to the mobilization of the body's defenses, while the subsequent marked increase indicates the start of damage processes and set the inflammatory stage in the course of traumatic disease in TBI.

\section{С. В. Зябліцев, С. В. Піщуліна, С. В. Колеснікова, Р. М. Борис}

\section{СИСТЕМНІ ПРОЯВИ НЕСПЕЦИФІЧНОӤ ЗАПАЛЬНОЇ РЕАКЦЇ̈ ПРИ ТРАВМАТИЧНІЙ ХВОРОБІ ГОЛОВНОГО МОЗКУ}

Наведено аналіз динаміки при важкій експериментальній черепно-мозковій травмі вмісту у крові циркулюючих імунних комплексів, С-реактивного білка, церулоплазміну та прозапальних цитокінів. Виявлена загальна закономірність реакції маркерів прозапального каскаду з максимальним їх приростом на другу добу післятравматичного періоду, що відображало первинну активацію запальної реакції, а у подальшому - iï генералізацію. Максимальний приріст вмісту у крові цитокінів, особливо, IL-1 $\beta$, в цей період вказував на прогресування процесів пошкодження та формування стадії системної запальної реакції у перебігу травматичної хвороби головного мозку.

Ключові слова: травматична хвороба головного мозку; білки гострої фази запалення; прозапальні цитокіни.

Украӥнський науково-практичний центр ендокринної хірургії, трансплантації ендокринних органів і тканин Міністерства охорони здоров'я України, Київ
С. В. Зяблицев, С. В. Пищулина,

С. В. Колесникова, Р. Н. Борис

СИСТЕМНЫЕ ПРОЯВЛЕНИЯ НЕСПЕЦИФИЧЕСКОЙ ВОСПАЛИТЕЛЬНОЙ РЕАКЦИИ ПРИ ТРАВМАТИЧЕСКОЙ БОЛЕЗНИ ГОЛОВНОГО МОЗГА

Приведен анализ динамики при тяжелой экспериментальной черепно-мозговой травме содержания в крови циркулирующих иммунных комплексов, С-реактивного белка, церулоплазмина и провоспалительных цитокинов. Выявлена общая закономерность реакции маркеров провоспалительного каскада с максимальным их приростом на вторые сутки посттравматического периода, что отражало первичную активацию воспалительной реакции, а впоследствии - ее генерализацию. Максимальный прирост содержания в крови цитокинов, особенно, IL-1 $\beta$, в этот период указывал на прогрессирование процессов повреждения и формирования стадии системной воспалительной реакции в течении травматической болезни головного мозга.

Ключевые слова: травматическая болезнь головного мозга; белки острой фазы воспаления; провоспалительные цитокины.

\section{REFERENCES}

1. Vologzhanin DA. The metabolic bases of secondary immune deficiency at traumatic disease [dissertation]. St. Petersburg [Russia]: Kirov War-Med. Academy; 2005. [Russian].

2. Jelskyy VN, Ziablitsev SV, Pishchulina SV, et al. The role of neuroimmunoendocrine mechanisms in the formation of endogenous intoxication in traumatic disease. Tauride Med and Biol Bull. 2012;15(3):115-7. [Russian].

3. Clausen F, Hảnell A, Bjtsrk M, et al. Neutralization of interleukin-1beta modifies the inflammatory response and improves histological and cognitive outcome following traumatic brain injury in mice. Eur J Neurosci. 2009;30(3):385-96.

4. Abu Saleh Ammar Ibrahim. The role of cytokines in the pathogenesis of the acute period of traumatic brain injury [dissertation]. Moscow : Tver State Med. Academy; 2007. [Russian].

5. Sadova VA. The processes of lipid peroxidation and cytokine response in acute traumatic brain injury in the right- and left-hemispheric brain damage [dissertation]. Chelyabinsk (Russia): Ural State Univ.; 2008. [Russian].

6. Sokolova TF. The interaction of the immune, nervous and endocrine systems in traumatic disease [dissertation]. Omsk : Omsk State Med. Academy; 2004. [Russian].

7. Kuchin DG. Pathophysiological role (predictive value) of metalloproteins (ferritin and ceruloplasmin) in the acute period of traumatic brain and cranial-facial injuries [dissertation]. Chelyabinsk (Russia): Ural State Univ.; 2005.

8. Patyukov KA. Optimization of the pathogenetic evaluation 
of endotoxemia in patients with traumatic brain disease [dissertation]. Omsk : Omsk State Med. Academy; 2008. [Russian].

9. Ziablitsev SV. The pathogenesis of the neuroregulatory systems disorders at the acute period of traumatic brain disease caused by traumatic brain injury[dissertation]. Donetsk : Gorky National Med. Univ.; 2005. [Ukrainian].

10. Gordon JW, Shaw JA, Kirshenbaum LA. Multiple facets of NF-kB in the heart: to be or not to NF-kB. Circ Res. 2011;108(9):1122-32.

Received 19.05.2015 